\title{
Effect of Kangaroo care on Vulnerable Infant Syndrome in mother
}

\section{Melike Yavaş Çelik \& Zerrin Çiğdem}

To cite this article: Melike Yavaș Çelik \& Zerrin Çiğdem (2021): Effect of Kangaroo care on Vulnerable Infant Syndrome in mother, Early Child Development and Care, DOI: 10.1080/03004430.2021.1932859

To link to this article: https://doi.org/10.1080/03004430.2021.1932859

\section{Published online: 27 May 2021.}

Submit your article to this journal $₫$

Џ Article views: 38

Q View related articles $\sqsubset$

View Crossmark data 


\title{
Effect of Kangaroo care on Vulnerable Infant Syndrome in mother
}

\author{
Melike Yavaş Çelik (1) ${ }^{a}$ and Zerrin Çiğdem (iD ${ }^{b}$

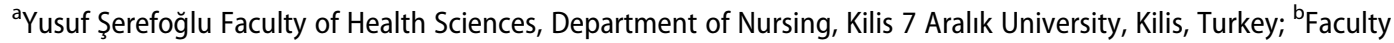 \\ of Health Sciences, Department of Nursing, Hasan Kalyoncu University, Gaziantep, Turkey
}

\begin{abstract}
This study aims to examine the effect of kangaroo care on Vulnerable Infant Syndrome (VIS) in the mother. The sample group consisted of 58 preterm infants, 27 of whom were control and 31 were experimental groups. Data were collected using the question form, the Vulnerable Baby Scale (VBS), the Edinburgh Post PartumDepression Scale (EPDS), the Maternal Attachment Scale (MAS). The mean scores of VBS were found in the kangaroo group $(17.22 \pm 0.96)$ and in the control group $(43.66 \pm 0.89)$. It was found that there was a significant difference between the two groups in terms of VBS scores $(p<0.01)$. In addition, the mothers in the experimental group compared to the mothers in the control group; the mean EPDS score was low and the MAS mean score was high $(p<0.01)$.It was determined kangaroo care reduces maternal vulnerability, postpartum depression and increases maternal attachment.
\end{abstract}

\section{ARTICLE HISTORY}

Received 11 December 2020

Accepted 17 May 2021

\section{KEYWORDS}

Vulnerability perception; mothers; new-born; preterm; kangaroo care

\section{Introduction}

Expectations have an important place on the basis of social relations. The way mothers perceive their babies and their expectations from them are extremely important in their relationships with their babies. These perceptions and expectations can affect both the mother's caring behaviour and the baby's developmental steps. Mothers have positive expectations from the moment they conceive. However, an adverse situation that may occur before, during or after birth can change mothers' expectations and perceptions of their babies. Vulnerable Infant Syndrome(VIS) may develop in mothers who perceive their babies as sensitive (Green \& Solnit, 1964; Maclean, 2010; Stern, Karraker, McIntosh, Moritzen, \& Olexa, 2006).

Green and Solnit defined (VIS) in 1964 as the worry that mothers will lose their children in a short time, although children are healthy after a life-threatening illness (Green \& Solnit, 1964; Stern et al., 2006). In the literature, preterm birth, pregnancy and perinatal complications, pospartum depression, babies acquired with assisted reproductive techniques, feeding problems and crying behaviours in infancy, intensive care or hospitalization, situations requiring prolonged separation from the baby, family anxiety, maternal depression and low social support, having a single child, previous losses, socio-economic level of the family, education level, parents' health status, parents' attitude towards child rearing, parents' self-efficacy are defined risk factors for vulnerable baby / child syndrome (Akça, 2012; De Ocampo, Macias, Saylor, \& Katikanemi, 2003; Doğan, Ertem, Karaaslan, \& ve Forsyth, 2009; Erdeve, Atasay, Arsan, \& Türmen, 2008; Forsyth, Horwitz, Leventhal, \& Burger, 1996; Green \& Solnit, 1964; Leslie \& Boyce, 1996; Maclean, 2010; Mcgrath, Samra, Zukowsky, \& Baker, 2010; Stern et al., 2006). 
Since the risk of perception of vulnerability is quite high in mothers with preterm and low birth weight babies (Allen et al., 2004; Kerruish, Settle, Campbell-Stokes, \& Taylor, 2005; Maclean, 2010; Metin, Yıldız, \& Saçan, 2016), these babies and their mothers need to be better monitored and supported (Chambers, Gittens, \& Leonard, 2011; Forsyth et al., 1996; Guralnick, 1998; Horwitz et al., 2015; Pearson \& Boyce, 2004; Perrin, West, \& Culley, 1989). The mother has a biological and psychological relationship with her baby. The mother is the child's first caregiver, first guardian and first contact person from the first days of her life. Attachment is a condition that develops between mother and baby, improves the baby's sense of trust and supports the baby's neurodevelopment. Starting attachment as early as possible is necessary for the baby's psychological, physical, social development and gaining a sense of trust (Sahin \& Karabekiroğlu, 2018; Unal \& Çak Esen, 2018). It has been determined that kangaroo care is an application that increases mother-infant communication, initiates a healthy relationship between them, supports the healthy development of the baby and reduces the postpartum stress of the mother (Adeli \& Alirezaei, 2018; Angelhoff et al., 2018; Çetinkaya \& Ertem, 2017). For this reason, it has been stated that the application of kangaroo care will be beneficial in the start of the mother and baby union and breastfeeding as early as possible in the postnatal period (Sarparast, Farhadi, Sarparast, \& Shafai, 2015; Susan, 2013).

In addition, kangaroo care has been reported in the literature as a method that positively affects mother-infant attachment, father-infant attachment, baby's growth and development parameters, breastfeeding, early discharge, release of breast milk, painful procedures and facilitates the work of healthcare professionals (Hardy, 2011; Kwah, Whiteman, Grunfeld, Niccols, \& Wood, 2018; Sarparast et al., 2015; Susan, 2013). Therefore, in this study, it was aimed to examine the effect of kangaroo care on the mother's Vulnerable Infant Syndrome (VIS).

\section{Methods}

\section{Hypotheses of research}

- There is a difference between the experimental and control groups in terms of mothers' VBS scores.

- There are no differences between experimental and control groups in terms of mothers' EPDS and MAS scores.

\section{Universe and sample of research}

The data of this experimental study were collected in the Neonatal Intensive Care Unit (NICU) of a private hospital between June and September 2019. The population of the study consisted of all babies and mothers in the NICU, and the samples consisted of 58 mothers and babies who did not have multiple pregnancy, had preterm birth, were primiparous, and had no communication problems. For sample selection, the vulnerable occurrence situations in Figure 1 have been utilized. In the NICU of the hospital, services are provided to 1st, 2nd and 3rd level patients. The unit has a total of 33 incubators, 9 of which can be turned into open beds optionally. A neonatal specialist, 3 paediatrician and 27 nurses work in the unit. The nurses worked in two different shifts between 08.00 18.00 and $18.00-08.00$ on weekdays and weekends. While 9 nurses work in the unit between 08.00 and 18.00 on weekdays, 8 nurses work on weekends and between 18.00 and 08.00 . The number of babies per nurse in the unit varies between 3 and 4 . Kangaroo care is not routinely applied in the unit.

In order to prevent the mothers in the control group from being affected by the mothers in the intervention group and to increase the reliability, the babies and mothers of the control group were included in the study first. The sample selection in which the intervention and control groups were determined is shown in Figure 2. 
Maternal demographic / health /

/health/ psychological characteristics

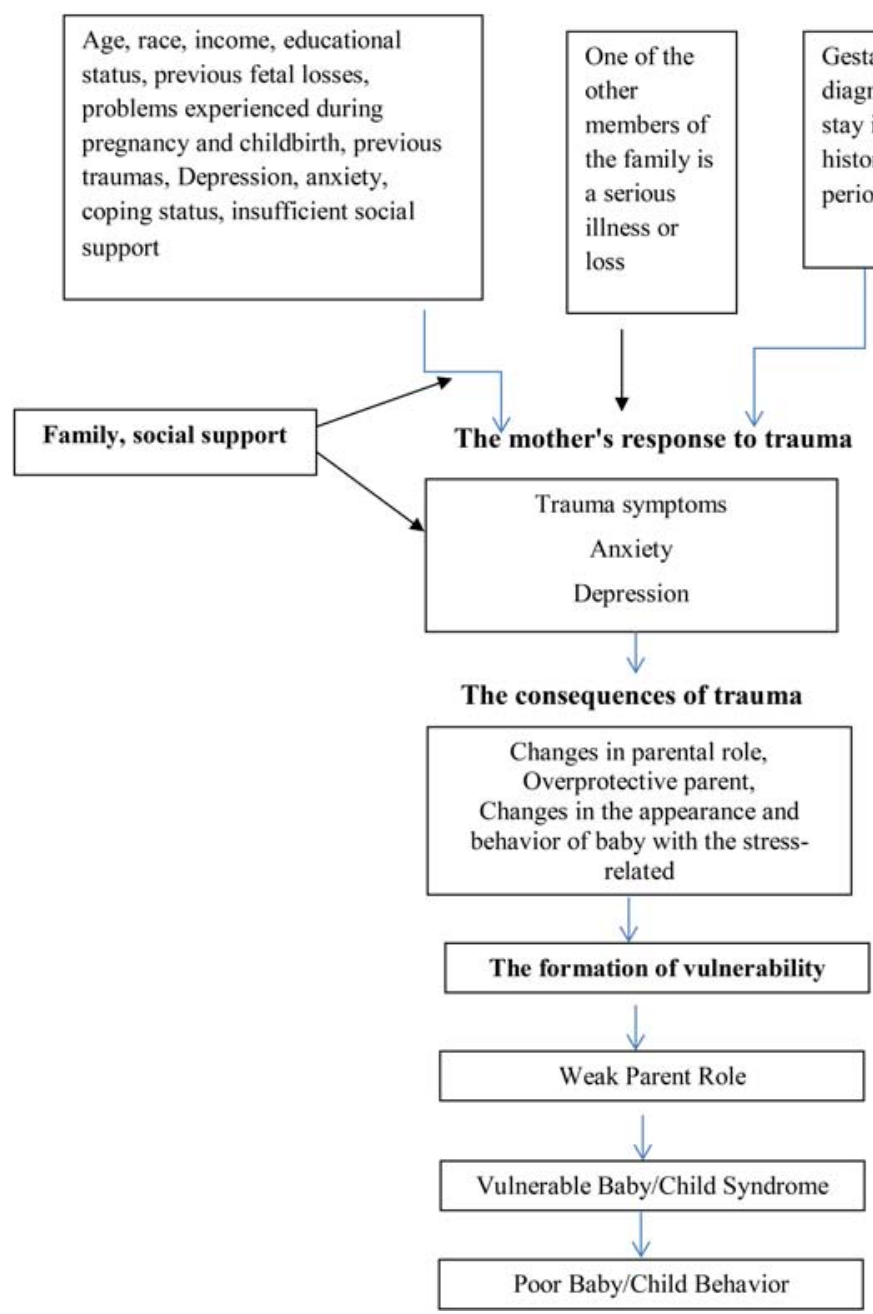

Orthers Demographic of the baby

characteristics psychological characteristics

Gestational age, weight, medical diagnosis, previous hospitalization, stay in the newborn unit, family history, having a disease in any period of life,

Figure 1. Theoretical Model Defining the Formation Phase of Vulnerability Perception (De Ocampo et al., 2003; Green \& Solnit, 1964; Horwitz et al., 2015; Maclean, 2010; Thomasgard \& Metz, 1995).

\section{Data collection tools}

Data were collected using Question Form, Edinburgh Postnatal Depression Scale, Maternal Attachment Scale, and Vulnerable Baby Scale. Permission to use the scales was obtained.

\section{Question Form}

The Question Form prepared by the researchers, includes demographic data about the mother and the infant, and questions about the prenatal, during period and postnatal, which are thought to affect be the mother's perception of vulnerability.

\section{Edinburgh Postnatal Depression Scale (EPDS)}

The scale was developed by Cox and Holden (1987). Adapted to Turkish by Engindeniz, Küey, and Kültür (1996). It is used to determine the risk for depression in the postnatal period and to 


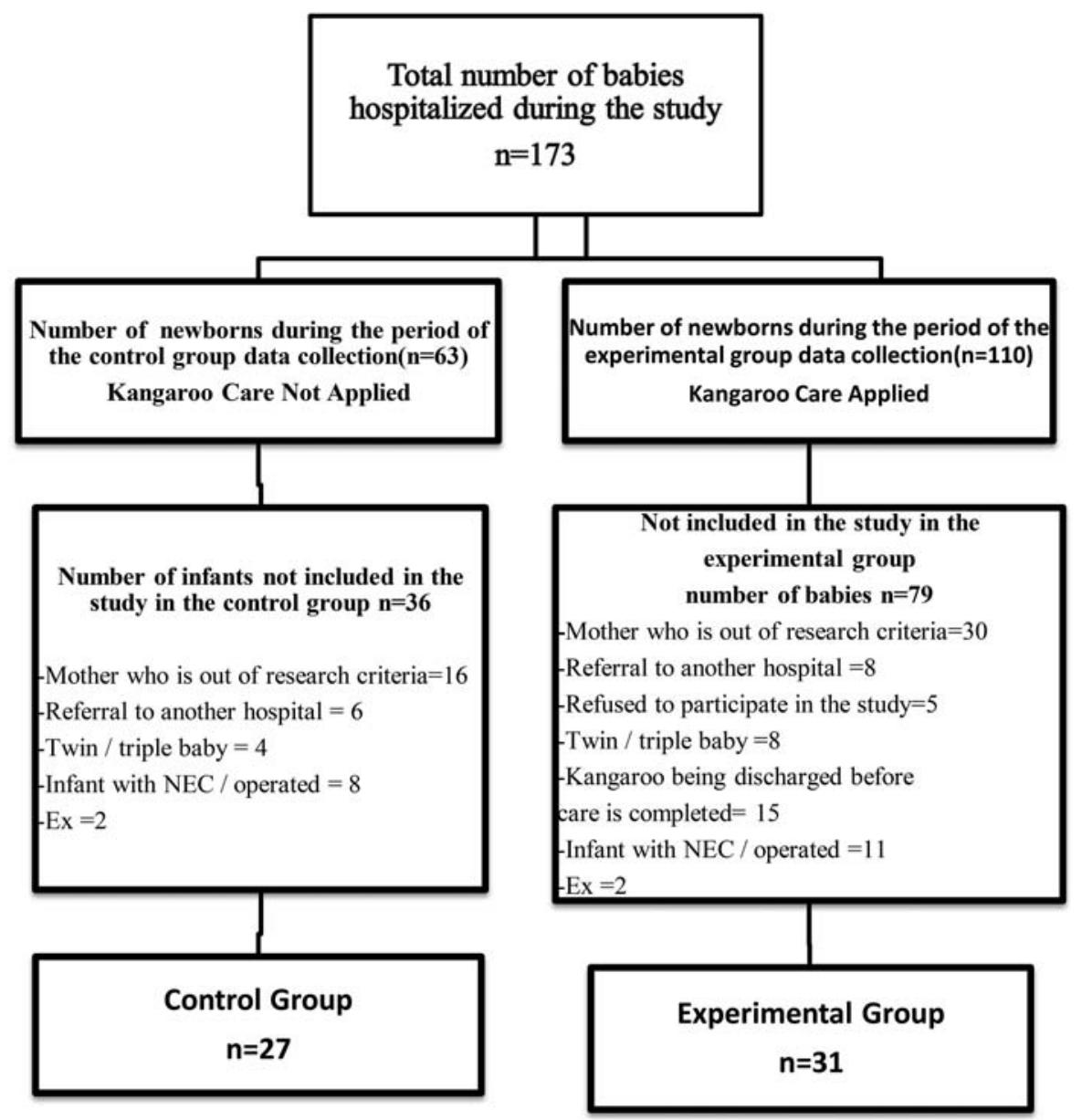

Figure 2. Sample selection of control and experimental group.

measure the level and change of violence. It is a self-assessment scale. It is applied to postpartum women. It contains a total of 10 questions and measures depression. It provides a four-point Likert type measurement. The directive is at the beginning of the scale and subjects are asked to mark the substance most relevant to their situation when filling in the subjects. Scoring of each item is different. Items $3,5,6,7,8,9$, and 10 show decreasing violence and scoring is 3, 2, 1, 0 . On the other hand, items 1,2 and 4 are scored in the form of $0,1,2,3$. The total score of the scale is obtained by adding these item scores. As a result of the cut-off point scale study conducted in Turkey and it has ben calculated as 12/13 (Cox \& Holden, 1987; Engindeniz, 1996).

\section{Maternal Attachment Scale (MAS)}

Maternal Attachment Scale was developed by Mary E. Muller in 1994 to measure attachment with maternal love (Muller \& Mercer, 1993). Muller developed the MAS questions in the light of the literature examining maternal adaptation and maternal attachment and tested maternal attachment in two phases. Muller used Mercer's Maternal Role Adaptation theory to identify these phases.

According to this theory, the first phase occurs on average one month after birth, the physical recovery phase. In this phase, the mother is busy with her own care and the care of her baby. During this phase, the mother socially and psychologically adapts to motherhood. The second phase is the success phase in which the maternal identity is completed in four or five months 
after birth. In this phase, maternal behaviours, sense of attachment to the baby and maternal adequacy are at the highest level. The phase completed in the eighth month after birth is the rupture phase. Cronbach's alpha reliability coefficient was found to be 0.85 (Muller \& Mercer, 1993). Adaptation to Turkish was made by Kavlak and Sirin(2009).

\section{Vulnerable Baby Scale (VBS)}

Vulnerable Baby Scale was developed by Kerruish et al. (2005). The scale consists of 10 questions and is a 5-point likert type. The total score of the scale is 50. A score of 27 and above indicates that the perception of vulnerability is high. In the study conducted by Kerruish et al., (2005), the reliability coefficient of the scale was found to be Cronbachalpha 0.70 (Kerruish et al., 2005). The validity and reliability of the scale in Turkey was done by Yavaş Çelik and Çiğdem (2020). Scale's Cronbach alpha was found to be 0.84 in this study (Yavaş Çelik \& Çiğdem, 2020).

\section{Training material}

A two-stage training programme was organized by the researchers, one-to-one applied to mothers in the experimental group to be treated with kangaroo. In the first phase of the training programme; The training tool prepared as a power-point presentation, including the definition of kangaroo care, its benefits for mother and baby, application methods, duration of application, and which babies it will be applied. After this presentation, in the second stage; Kangaroo care was applied to the mothers by using model doll (Model doll used in nursing education).

\section{Application of research}

The mothers in the control group were given information about the study at the first encounter and written and verbal permissions were obtained. The Question Form, EPDS and MAS were administered. No attempt was made to the babies and their mothers in this group, except for the routine care provided in the NICU. Two weeks (15 days) after the babies were discharged from the NICU, EPDS and MAS were administered again by talking to the mothers on the phone. Later, mothers in this group were invited to the hospital, trained and practiced kangaroo care so that the mothers and babies were not deprived of kangaroo care.

The mothers in the experimental group were informed about the study in the first interview and after their written and verbal permissions were obtained, they were asked to answer the Question Form, EPDS and MAS. Then, a training programme on Kangaroo Care (KC) was implemented. The mothers were supported in KC application and the application was started when both mothers and babies were ready for application. The application was applied at least once a day and for 30 min, 5 days in a row. The application started with $15 \mathrm{~min}$ and then the time increased gradually. During KC, the mother placed her baby between two breasts, and the baby's breast was placed on the mother's breast in an upright position. During the application of KC, a quiet, calm and suitable environment was created so that comfort of the baby and mother would not be disturbed. One of the relatives or friends joined the practice to support the mother's feeling of comfort. The application steps of the mother's KC were observed by the researcher and the deficiencies, if any, were corrected by discussing with the mother during / after the application.

After this 5-day practice, mothers were encouraged to continue with KC until their babies are discharged from the NICU. Two weeks (15 days) after the babies were discharged from the NICU, the mothers were interviewed on the phone and EPDS and MAS was applied for the second time and VBS was applied for the first time and the interview was ended by thanking the participant for his support to the study. You can look at Figure 3 for the details of the application. 


\section{Ethical aspect of the research}

Permission was obtained from the Ethics Committee of the Faculty of Health Sciences of a University. The volunteers of the participants were taken as basis. Interviews were held with the participants who agreed to participate at an available time. The research was conducted in line with the Helsinki Research Declaration Principles.

\section{Statistical analysis of data}

For the analyses, the SPSS package programme was used. All results were evaluated at $95 \%$ confidence interval and $p<0.05$. Before starting the study; Calculated using $\mathrm{G} *$ Power (Faul, Erdfelder,

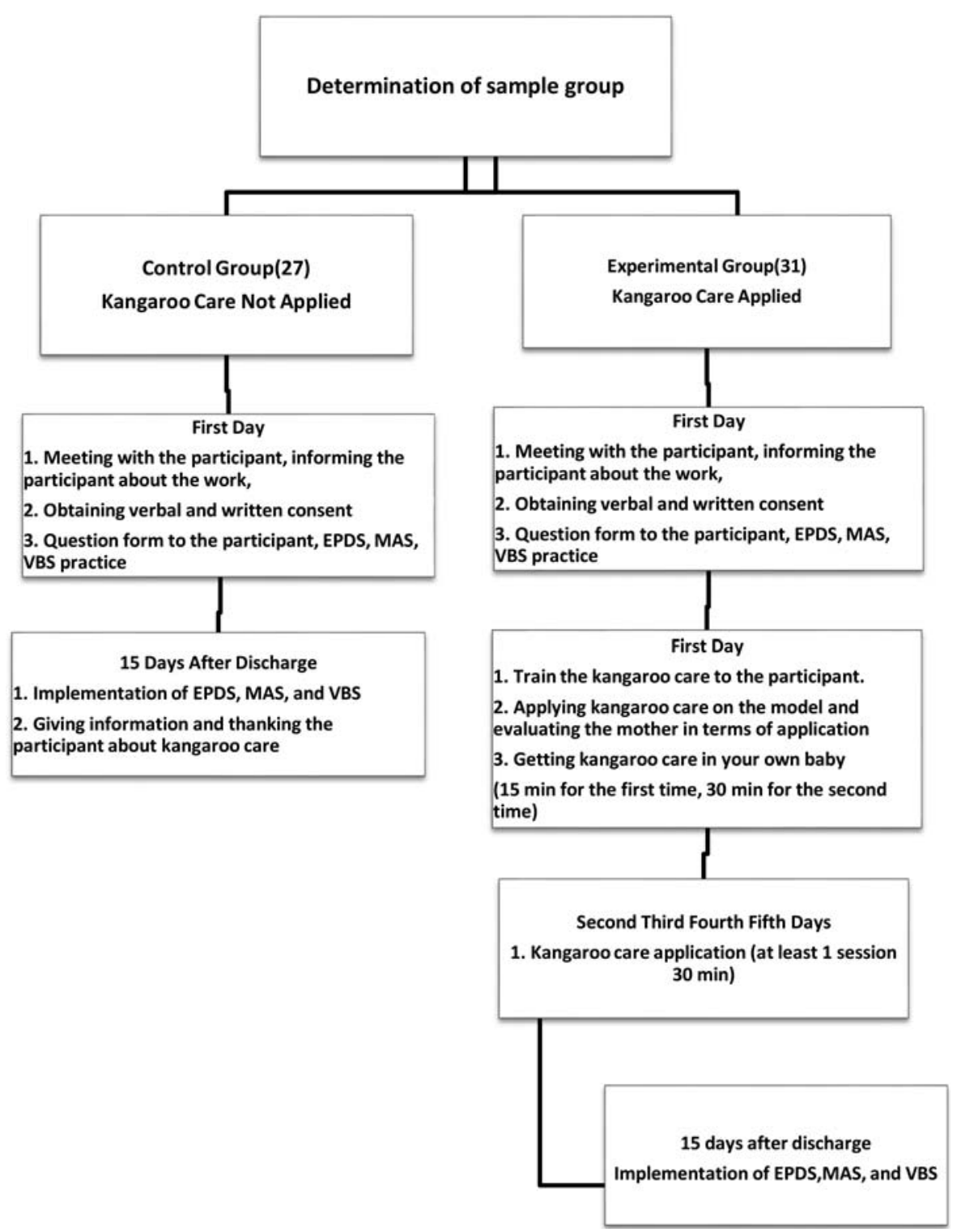

Figure 3. Flow chart for the experimental study we attempted. 
Lang, \& Buchner, 2007) programme for power analysis. The first type of error was 0.05 and Cohen's effect width was taken as 0.8 and the sample was determined as 24 people for each group (Cohen, 1969). The power calculated according to these inputs was found to be $86 \%$. In determining our sample, we determined these values by considering.

In descriptive statistics; number and percentage in statistics determined by number, mean \pm standard deviation and minimum-maximum ( $\min -\max$ ) analyses were used for the variables determined by the measurement. In order to investigate the differences between the groups, $t$-test in independent groups and dependent groups with normal distribution. Also $t$ test was employed to determine the homogeneity between the two groups.

\section{Findings}

When we compared the demographic data between the groups, there was determined no difference between the groups in terms of mother age, father age, postnatal age of the baby, gestational age and weight of baby. There was no statistically significant difference between the two groups ( $p>$ 0.05) (Table 1) As it is understood based on these results, the values are homogeneous in both groups; and there are no significant differences between them that will affect the reliability of the study.

In research were found control group' mother age mean $26.22 \pm 8.07$, father age mean $28.66 \pm$ 8.79, newborns' postnatal age (day) mean $19.40 \pm 15.17$, gestational age(week) $33.07 \pm 1.73$, weight of newborn (gr) $2251.85 \pm 420.71$ and experiment group' mother age mean $24.74 \pm 6.97$, father age mean $30.00 \pm 7.94$, newborn' postnatal age (day) mean 16.29 \pm 11.67 , gestational age (week) $34.03 \pm 2.52$, weight of newborn (gr) $2153.77 \pm 487.95$ (Table 1).

When we compared the demographic data between the groups, there was determined no difference between the groups in terms of mother age, father age, postnatal age of the newborn, gestational age and weight of newborn. There was no statistically significant difference between the two groups ( $p>0.05$ ) (Table 1).

When the education levels of the mothers in the study groups were examined; it was determined that primary school and below education level was $77.8 \%(n=21)$ in the control group and $71.0 \%$ ( $n$ $=22$ ) in the experimental group. Also the education levels of fathers were determined that the primary school and below education level was $66.7 \%(n=18)$ in the control group and $74.2 \%$ ( $n=$ $23)$ in the experimental group. It was found that $70.4 \%(n=19)$ of the control group and $80.6 \%$ $(n=25)$ of the experimental group were nuclear type families. It was observed that $96.3 \%(n=26)$ of the mothers in the control group and $80.6 \%(n=25)$ of the mothers in the experimental group did not work. It was determined that the families expressed their income as higher / balanced than their expenses in 66.7\% $(n=18)$ in the control group and $83.9 \%(n=26)$ in the experimental group (Table 2).

When the properties related to pregnancy are examined; the natural conception rate of mothers was found to be $77.8 \%(n=21)$ in the control group and $87.1 \%(n=27)$ in the experimental group. It

Table 1. Evaluation of demographic data affecting vulnerability and homogeneity between groups.

\begin{tabular}{|c|c|c|c|c|c|}
\hline Data & Group & $n$ & $X \pm$ S.S. & $T$ & $p$ \\
\hline \multirow[t]{2}{*}{ Mother age } & Control group & 27 & $26.22 \pm 8.07$ & & \\
\hline & Experiment group & 31 & $24.74 \pm 6.97$ & 0,74 & 0.45 \\
\hline \multirow[t]{2}{*}{ Father age } & Control group & 27 & $28.66 \pm 8.79$ & & \\
\hline & Experiment group & 31 & $30.00 \pm 7.94$ & 0.60 & 0.54 \\
\hline \multirow[t]{2}{*}{ Postnatal age(day) } & Control group & 27 & $19.40 \pm 15.17$ & & \\
\hline & Experiment group & 31 & $16.29 \pm 11.67$ & 0.88 & 0.38 \\
\hline \multirow[t]{2}{*}{ Gestational age (week) } & Control group & 27 & $33.07 \pm 1.73$ & & \\
\hline & Experiment group & 31 & $34.03 \pm 2.52$ & 1.62 & 0.10 \\
\hline \multirow[t]{2}{*}{ Weight of newborn (gr) } & Control group & 27 & $2251.85 \pm 420.71$ & & \\
\hline & Experiment group & 31 & $2153.77 \pm 487.95$ & 0.81 & 0.41 \\
\hline
\end{tabular}


was determined that $51.9 \%(n=14)$ of mothers in the control group, $48.4 \%(n=15)$ of mothers in the experimental group had the threat of miscarriage in these pregnancies and $63.0 \%(n=17)$ of mothers in the control group, $51.6 \%(n=16)$ of mothers in the experimental group had in cesarean section. The gender of the newborns was determined as male $63.0 \%(n=17)$ in the control group and $51.6 \%(n=16)$ in the experimental group (Table 2$)$.

In the study, there was no statistically significant difference between the control and experimental groups in terms of parental education level, family type, working status of the mother, family income level, way of conception of the mother, miscarriage threat, delivery type and gender of the baby, and the groups were found to be homogeneous ( $p>0.05$ ) (Table 2).

When the mean scores of the mothers in the control and experimental groups measured on the 15th day after discharge (last measurement) were examined; The mean VBS score was $43.66 \pm 4.63$ in the control group, $17.22 \pm 5.39$ in the experimental group, and the difference was statistically significant $(p<0.001)$. The mean EPDS score of the mothers was found to be $17.22 \pm 7.95$ in the control group and $4.48 \pm 5.38$ in the experimental group, and the mean EPDS score was found to be statistically significant between the groups $(p<0.001)$. The mean MAS score was $90.85 \pm 8.26$ in the control group and $99.19 \pm 9.26$ in the intervention group, and the mean MAS score was found to be statistically significant between the groups $(p<0.01$ ) (Table 3 ).

In the study, it was found that the mothers who did not apply KC in the control group had a EPDS mean score of $18.07 \pm 7.59$ in the first measurement (pre-test) and $17.22 \pm 7.95$ in the last test (posttest), and the EPDS scores were not statistically significant between the two measurements averages ( $p>0.05$ ). In the experimental groups, the first measurement (pre-test) EPDS score average of the mothers who applied KC was found to be $20.70 \pm 6.41$, and the final measurement average (post-

Table 2. Comparison of some qualitative features that can affect vulnerability perception between control and interference group in terms of homogeneity.

\begin{tabular}{|c|c|c|c|c|c|}
\hline Data & $\begin{array}{c}\text { Control Group } \\
n=27 \%\end{array}$ & $\%$ & $\begin{array}{c}\text { Experiment Group } \\
n=31 \%\end{array}$ & $\%$ & $\begin{array}{c}\text { Analysis Values } \\
\mathrm{X}^{2}\end{array}$ \\
\hline \multicolumn{6}{|l|}{ Mother education } \\
\hline Primary school graduate and down & 21 & 77.8 & 22 & 71.0 & $X^{2}=0.34$ \\
\hline Secondary education and above & 6 & 22.2 & 9 & 29.0 & $p>0.05$ \\
\hline \multicolumn{6}{|l|}{ Father education } \\
\hline Primary school graduate and down & 18 & 66.7 & 23 & 74.2 & $X^{2}=0.39$ \\
\hline Secondary education and above & 9 & 33.3 & 8 & 25.8 & $p>0.05$ \\
\hline \multicolumn{6}{|l|}{ Family type } \\
\hline Nuclear family & 19 & 70.4 & 25 & 80.6 & $X^{2}=0.83$ \\
\hline Extended family & 8 & 29.6 & 6 & 19.4 & $p>0.05$ \\
\hline \multicolumn{6}{|l|}{ Working status of mothers } \\
\hline Working & 1 & 3.7 & 6 & 19.4 & Fisher's Exact \\
\hline Housewife & 26 & 96.3 & 25 & 80.6 & $\begin{array}{l}p=0.10 \\
p>0.05\end{array}$ \\
\hline \multicolumn{6}{|l|}{ Economical situation } \\
\hline Less than income & 9 & 33.3 & 5 & 16.1 & Fisher's Exact, \\
\hline Income is more than expenditure and balanced & 18 & 66.7 & 26 & 83.9 & $\begin{array}{l}p=0.21 \\
p>0.05\end{array}$ \\
\hline \multicolumn{6}{|l|}{ If the mother has a low risk of pregnancy } \\
\hline Yes & 14 & 51.9 & 15 & 48.4 & $X^{2}=0.69$ \\
\hline No & 13 & 48.1 & 16 & 51.6 & $p>0.05$ \\
\hline \multicolumn{6}{|l|}{ How the mother got pregnant } \\
\hline Naturally & 21 & 77.8 & 27 & 87.1 & Fisher's Exact, \\
\hline With assisted reproductive technique & 6 & 22.2 & 4 & 12.9 & $\begin{array}{l}p=0.48 \\
p>0.05\end{array}$ \\
\hline \multicolumn{6}{|l|}{ Mother's way of birth } \\
\hline Normal birth & 10 & 37.0 & 15 & 48.4 & $X^{2}=0.75$ \\
\hline Cesarian section & 17 & 63.0 & 16 & 51.6 & $p>0.05$ \\
\hline \multicolumn{6}{|l|}{ Newborn Sex } \\
\hline Male & 10 & 37.0 & 15 & 48.4 & $X^{2}=0.75$ \\
\hline Women & 17 & 63.0 & 16 & 51.6 & $p>0.05$ \\
\hline
\end{tabular}


Table 3. Comparison of the mean scores of VBS, EPDS and MAS after Kangaroo care.

\begin{tabular}{|c|c|c|c|c|}
\hline Scales & $\begin{array}{c}\text { Control group }(n=27) \\
\qquad \pm \pm S . S\end{array}$ & $\begin{array}{l}\text { Experiment group }(n=31) \\
\qquad X \pm S . S\end{array}$ & $t$ & $p$ \\
\hline VBS & $43.66 \pm 4.63$ & $17.22 \pm 5.39$ & 19.86 & 0.000 \\
\hline EPDS & $17.22 \pm 7.95$ & $4.48 \pm 5.38$ & 7.125 & 0.000 \\
\hline MAS & $90.85 \pm 8.26$ & $99.19 \pm 9.26$ & 3.59 & 0.001 \\
\hline Paired samples test & & & & \\
\hline
\end{tabular}

test) was found to be $4.48 \pm 5.38$, and statistical significance was observed between the two measurement averages $(p<0.001)$ (Table 4).

The first measurement(pre-test) MAS score mean of the mothers in the control group who didn't apply KC was found to be $90.70 \pm 8.47$ and the last measurement(final test) as $90.85 \pm 8.26$, and there was no statistically significant difference between the measurement MAS score averages $(p>0.05)$. The first measurement(pre-test) MAS mean score of the mothers in the experimental group was $85.09 \pm 12.50$ and the last measurement(final test) MAS score of mother was $99.19 \pm 9.26$, and a statistically significant difference was found between the two measurements $(p<0.01)$. (Table 4$)$.

After Kangaroo care, it was determined that there was a high positive correlation between the mean scores of VBS and EPDS $(r=0.76, p<0.05)$ (Table 5$)$. It was determined that there was a negative correlation between the mean scores of VBS and MAS $(r=-0.52, p<0.05)$. There was a negative correlation between EPDS and MAS mean scores $(r=-0.27, p<0.05)$.

\section{Discussion}

The presence of the baby in the neonatal intensive care unit is a very troublesome process for a parent (Russell et al., 2014). In one study, many problems were expressed by families such as the baby being born earlier than expected, being small, not being able to take care of the baby because of health problems, not being able to touch the babies and feeding them whenever they wanted (Rao, Udani, \& Nanavati, 2008). There are many studies indicating that having a preterm baby adversely affects the perception of vulnerability (Chambers et al., 2011; Guralnick, 1998; Horwitz et al., 2015; Kerruish et al., 2005; Maclean, 2010; Metin et al., 2016; Pearson \& Boyce, 2004; Perrin et al., 1989; Tallandini, Morsan, Gronchi, \& Macagno, 2015) and it has been reported that the perception of vulnerability can be improved with kangaroo care which has proven to contribute to the maintenance of the attechment between parents and preterm infants and supported by UNICEF and WHO (Lasiuk, Comeau, \& Newburn-Cook, 2013; UNICEF, 2017; Venancio \& Almeida, 2004; WHO, 2012; WHO, 2015). Therefore, in this study, we aimed to examine the effect of KC on mother's VIS. In our study, the mean score of VBS was found to be $17.22 \pm 5.39$ in the experimental group treated with kangaroo care and $43.66 \pm 0.4 .63$ in the control group (Table 3). In the light of this information, we can say that kangaroo care positively affects the perception of vulnerability.

Table 4. Evaluation of EPDS and MAS score before and after kangaroo care in groups.

\begin{tabular}{llllllrrr}
\hline Scales & Control group & & & \multicolumn{4}{c}{ Experiment group } \\
& Pre-test $(n=27)$ & Final test $(n=27)$ & $t$ & $p$ & Pre-test $(n=31)$ & Final test $(n=31)$ & $t$ & $p$ \\
\hline & $\mathrm{X} \pm \mathrm{S} . \mathrm{S}$ & $\mathrm{X} \pm \mathrm{S} . \mathrm{S}$ & & & $\mathrm{X} \pm \mathrm{S} . \mathrm{S}$ & $\mathrm{X} \pm \mathrm{S} . \mathrm{S}$ & \\
EPDS & $18.07 \pm 7.59$ & $17.22 \pm 7.95$ & 1.96 & 0.06 & $20.70 \pm 6.41$ & $4.48 \pm 5.38$ & 12.26 & 0.00 \\
MAS & $90.70 \pm 8.47$ & $90.85 \pm 8.26$ & 0.28 & 0.77 & $85.09 \pm 12.50$ & $99.19 \pm 9.26$ & 7.50 & 0.001 \\
Paired samples test & & & & & & & & \\
\hline
\end{tabular}

Table 5. Correlation of mean scores of PBL, EPDS and MBL after kangaroo care.

\begin{tabular}{lcccc}
\hline Scales & EPDS & MAS & & \\
& $r$ & $p$ & -0.52 & 0.000 \\
\hline VBS & 0.76 & 0.000 & 0.035 & \\
EPDS & - & -0.27 & & \\
\hline
\end{tabular}


In addition, after the kangaroo care application, the mean scores of both EPDS and MAS between the groups were found to be statistically significant $(p<0.01)$ (Table 3 ). These results showed that kangaroo care reduces maternal depression and increases maternal attachment. Studies have reported that kangaroo care reduces anxiety in mothers in the first three days after birth (Moore, Anderson, Bergman, \& Dowswell, 2014; Phillips, 2013). In a meta-analysis study, it was reported that the perception of vulnerability may be caused by psychological factors such as anxiety of the parents (Tallandini et al., 2015). It is highlighted that vulnerability may be related to the mother's beliefs in the study of Thomason, Flynn, Himle, and Volling (2015). In a study conducted by Ahn, Lee, and Shin (2010), maternal attachment scores were found to be high in the group applying kangaroo care.

In a study conducted with 150 mothers who had a preterm infant in the neonatal intensive care unit and had trauma, depression and anxiety symptoms, it was reported that mothers' perceptions of vulnerability were high (Horwitz et al., 2015). However, it was determined that the preparation of the mothers who have a preterm infant or the infant in the neonatal intensive care unit for any reason and the initiation of the maternal adaptation process may prevent the perception of vulnerability in these mothers (Henderson, Carson, \& Redshaw, 2016; Teti, Hess, \& O'Connell, 2005). In the study of Teti et al. (2005) found that support given to the mother during this adaptation process increased her self-confidence, facilitated coping with the preterm infant and prevented the formation of vulnerability perception. Therefore, in this study, the effect of KC on postpartum depression and attachment status of mothers was examined. The results of this situation in the study are discussed in detail below.

It was found that the mothers who did not apply KC in the control group had a EPDS mean score of $18.07 \pm 7.59$ in the first measurement (pre-test) and $17.22 \pm 7.95$ in the last test (post-test), and the EPDS scores were not statistically significant between the two measurements averages $(p>0.05)$. In the experimental groups, the first measurement (pre-test) EPDS score average of the mothers who applied KC was found to be $20.70 \pm 6.41$, and the final measurement average (post-test) was found to be $4.48 \pm 5.38$, and statistical significance was observed between the two measurement averages ( $p$ $<0.001$ ) (Table 4). Badr and Zauszniewskic (2017) in their study found that postpartum depression in mothers decreased with the kangaroo care.

In addition, the first measurement (pre-test) MAS score mean of the mothers in the control group who didn't apply KC was found to be $90.70 \pm 8.47$ and the last measurement (final test) as $90.85 \pm$ 8.26 , and there was no statistically significant between the measurement MAS score averages ( $p>$ 0.05). The first measurement (pre-test) MAS mean score of the mothers in the experimental group was $85.09 \pm 12.50$ and the last measurement (final test) MAS score of mother was $99.19 \pm 9.26$, and a statistically significant was found between the two measurements $(p<0.01)$. (Table 4). Lau et al. (2018) investigated the importance of KC for the initiation of attachment and its effect on the duration of early breastfeeding. As a result of this study, it was determined that mothers who started skin contact breastfeed earlier (Lau et al., 2018) In Herek's (2018) study, it was observed that kangaroo care increased the average of MAS scores.

The perception of vulnerability in mothers may be related to problems such as depression, anxiety, pessimism, inability to enjoy life (Allen et al., 2004). In another analysis of our study, it was determined that there was a high positive correlation between the mean scores of VBS and EPDS after kangaroo care $(r=0.76, p<0.05)$ (Table 5). Kerruish et al. (2005) determined in their study, that there was a positive medium-level correlation between EPDS and VBS mean scores (Kerruish et al., 2005). In addition, there was a moderate negative correlation between the mean scores of VBS and MAS $(r=-0.52, p<0.05)$ (Table 5$)$. All these results showed that $\mathrm{KC}$ positively affects postpartum depression and maternal attachment.

\section{Conclusions}

As a result, In our study, it was determined, kangaroo care which has many benefits in the literatüre, has a positive effect on the perception of vunerability, postpartum depression and maternal 
attachment. In this study, data show that kangaroo care is an effective method that may be prevent easily during vulnerability. Also, it is a cheap and easy method to apply for nurses. When this method is used in all newborn units, the formation of vulnerability perception can be stopped.

\section{Acknowledgments}

Patient consent was obtained from the participants in this study.

\section{Disclosure statement}

No potential conflict of interest was reported by the author(s).

\section{Author contributors}

MYC, ZC conceptualized the study and organized the data collection. MYC, ZC wrote the first draft of the manuscript. MYC, ZC run the analyses and wrote the results section. MYC contributed to revision of the final version of the manuscript.

\section{Notes on contributors}

Melike Yavaş Çelik, Phd. Kilis 7 Aralık University, Yusuf Şerefoğlu Faculty of Health Sciences, Department of Nursing, Kilis, Turkey.

Zerrin Çiğdem, Phd.Hasan Kalyoncu University Faculty of Health Sciences, Gaziantep.

\section{ORCID}

Melike Yavaş Çelik (D) http://orcid.org/000x0-0002-1155-1022

Zerrin Çiğdem (iD) http://orcid.org/0000-0002-2527-5700

\section{References}

Adeli, M., \& Alirezaei, S. (2018). A comparative study of the effects of skin contact and kangaroo care on mother's anxiety. Iranian Journal of Nursing and Midwifery Research, 23(4), 327-328.

Ahn, HYl, Lee, J., \& Shin, H. J. (2010). Kangaroo care on premature Infant growth and maternal attachment and postpartum depression InSouth korea. Journal of Tropical Pediatrics, 56(5), 342-344.

Akça, R. (2012). Ana- babaların Çocuk yetiştirmede aşırı koruyucu olmaları. Akademik Bakış Dergisi, 29, 1-13.

Allen, C. E., Manuel, J. C., Legault, C., Naughton, M. J., Pivor, C., \& O'Shea, M. (2004). Perception of child vulnerability among mothers of former premature infants. Pediatrics, 113(2), 267-273.

Angelhoff, C., Thernström, B. Y., Helmer, C. H., Olsson, E., Shorey, S., Frostell, A., \& Mörelius, E. (2018). Effect of Skin-to-Skin Contact on parents' sleep quality, mood, parent-infant interaction and cortisol concentrations in Neonatal Care units: Study protocol of a randomised controlled trial. BMJ Open, 8(7), 1-8.

Badr, H. A., \& Zauszniewskic, J. A. (2017). Kangaroo care and postpartum depression: The role of oxytocin. International Journal of Nursing Sciences, 4(2), 179-183.

Çetinkaya, E., \& Ertem, G. (2017). Ten tene temasın anne-preterm bebek Üzerine etkileri: Sistematik İnceleme. Hemşirelikte Eğitim ve Araştırma Dergisi, 14(2), 167-175.

Chambers, P. L., Gittens, M., \& Leonard, A. C. (2011). Vulnerable Child Syndrome, parental perception of child vulnerability, and emergency department usage. Pediatric Emergency Care, 27(11), 1009-1013.

Cohen, J. (1969). Statistical power analysis for the behavioural sciences. New York: Academic Press.

Cox, J. L., \& Holden, J. M. (1987). Detection of postnataldepression: Development of The 10-Item Edinburgh Postnatal depressionscale (EPDS). British Journal of Psychiatry, 150, 782-786.

De Ocampo, A. C., Macias, M. M., Saylor, C. F., \& Katikanemi, L. D. (2003). Caretaker perception of Child Vulnerability predicts Behavioral problems in NICU graduates. Child Psychiatry and Human Development, 34, 83-96.

Doğan, D. G., Ertem, I. O., Karaaslan, T., \& ve Forsyth, B. W. (2009). Perception of vulnerability among mothers of healthy infants in a middle- incomecountry. Child: Care, Health and Development, 35(6), 868-872. 
Engindeniz, N. (1996). Edinburgh Doğum sonu depresyon Ölçeği'nin Türkçe Formu için Geçerlilik ve güvenirlilik Çalışması. (yayımlanmamış Yüksek Lisans tezi). Ege Üniversitesi sağlık Bilimleri enstitüsü. İzmir: Hemşirelik Bölümü.

Engindeniz, A. N., Küey, L., \& Kültür, S. (1996). Edinburgh Doğum sonrası depresyon Ölçeği Türkçe Formu Geçerlilik ve güvenilirlik Çalışması. Bahar sempozyumları 1. Kitabı. Ankara. Psikiyatri Derneği Yayınları, 51-52.

Erdeve, Ö, Atasay, B., Arsan, S., \& Türmen, T. (2008). Yenidoğan Yoğun Bakım ünitesinde yatış deneyiminin aile ve Prematüre bebek Üzerine etkileri. Çocuk Sağlığı ve Hastalıkları Dergisi, 51, 104-109.

Faul, F., Erdfelder, E., Lang, A. G., \& Buchner, A. (2007). A. G*power 3: A flexible statistical power analysis program for the social, behavioral, and biomedical sciences. Behavior Research Methods, 39, 175-191.

Forsyth, B., Horwitz, S., Leventhal, J., \& Burger, J. (1996). The Child vulnerability scale: An instrument to measure parental perceptions of child vulnerability. Journal of Pediatric Psychology, 21, 89-101.

Green, M., \& Solnit, A. J. (1964). Reactions to the threatened loss of a child: A Vulnerable Child syndrome. Pediatrics, 34, 58-66.

Guralnick, M. (1998). Effectiveness of early intervention for vulnerable children: A developmental perspective. American Journal on Mental Retardation, 102(4), 319-345.

Hardy, W. (2011). Integration of kangaroo care into routine caregiving in the NICU. What is stopping you? Advances in Neonatal Care, 11(2), 119-121.

Henderson, J., Carson, C., \& Redshaw, M. (2016). Impact of preterm birth on maternal well-being and Women's perceptions of Their Baby: A population-based survey. BMJ Open, 6(10), e012676-8.

Herek, B. (2018). Yenidoğan Yoğun Bakımda Kanguru Bakımı Uygulanan Prematür Bebek Annelerinde Maternal Bağlanma ve Postpartum Depresyon. (Yayınlanmış Yüksek Lisans Tezi). T.C. Gazi Üniversitesi Sağlik Bilimleri Enstitüsü. Hemşirelik Anabilim Dali. Ankara.

Horwitz, S. M., Storfer-Isser, A., Kerker, B. D., Lilo, E., Leibovitz, A., John, N. S., \& Shaw, R. J. (2015). A model for the development of mothers's perceived vulnerability of preterm infants. Journal of Developmental \& Behavioral Pediatrics, 36 (5), 371-380.

Kavlak, O., \& Sirin, A. (2009). Maternal Bağlanma ölçeği'nin Türk toplumuna uyarlanması. Uluslararası Insan Bilimleri Dergisi, 6(1), 188-202.

Kerruish, N. J., Settle, K., Campbell-Stokes, P., \& Taylor, B. J. (2005). Vulnerable Baby Scale: Development and piloting of a questionnaire to measure maternal perceptions of their baby's vulnerability. Journal of Paediatrics and Child Health, 41(8), 419-423.

Kwah, K. L., Whiteman, B. L., Grunfeld, E. A., Niccols, C., \& Wood, E. (2018). Evaluation of an intervention to increase clinician knowledge and confidence to support breastfeeding, kangaroo care and positive touch within Neonatal units. Journal of Neonatal Nursing, 24, 94-99.

Lasiuk, G. C., Comeau, T., \& Newburn-Cook, C. (2013). Unexpected: Aninterpretive description of parental traumas' associated with preterm birth. BMC Pregnancy and Childbirth, 13(1), 1-10.

Lau, Y., Tha, P. H., Ho-Lim, S. S. T., Wong, L. Y., Lim, P. I., Citra Nurfarah, B. Z. M., \& Shorey, S. (2018). An analysis of the effects of intrapartum factors, neonatal characteristics, and Skin-To-Skin Contact on early breastfeeding initiation. Matern Child Nutrition, 14(1), 1-15.

Leslie, L. K., \& Boyce, W. T. (1996). The vulnurable child. Pediatrics in Review, 17(9), 323-326.

Maclean, P. C. 2010. Maternal perception of child vulnerability in preschoolers born very low birth weight. Clinical Psychology, University of New Mexico, Doctor of Philosophy Psychology.

Mcgrath, I. M., Samra, F. F. H., Zukowsky, K., \& Baker, B. (2010). Parenting after infertility: Issues for families and infant. MCN: The American Journal of Maternal/Child Nursing, 35(3), 156-164.

Metin, Ş, Yıldız, H., \& Saçan, S. (2016). 4-5 yaş Çocuğa sahip Annelerin Kırılganlık Algı Düzeyleri ve Kırılganlık Algı Düzeylerini etkileyen faktörlerin belirlenmesi. Uluslararası Erken Çocukluk Eğitimi Çalışmaları Dergisi, 1(2), 49-57.

Moore, E. R., Anderson, G. C., Bergman, N., \& Dowswell, T. (2014). Early Skin-To-Skin Contact For mothers and their healthy newborn infants. Cochrane Database Syst, 16(5), 1-75.

Muller, M. E., \& Mercer, R. T. (1993). Development of the prenatal attachment inventory. Western Journal of Nursing Research, 15(2), 199-215.

Pearson, S., \& Boyce, T. (2004). The Vulnerable Child syndrome. Pediatrics in Review, 25(10), 345-349.

Perrin, E., West, P., \& Culley, B. (1989). Is my child normal yet? Correlates of vulnerability. Pediatrics, 83(3), $355-363$.

Phillips, R. (2013). The sacred hour: Uninterrupted Skin-To-Skin Contact immediately after birth. Newborn and Infant Nursing Reviews, 13(2), 67-72.

Rao, S., Udani, R., \& Nanavati, R. (2008). Kangaroo mother care for low birth weight infants: A randomized controlled trial. Indian Pediatrics, 45, 17-23.

Russell, G., Sawyer, A., Rabe, H., Abbott, J., Gyte, G., Duley, L., \& Ayers, S. (2014). Parents' views on care of their very Prematüre babies in Neonatal intensive Care Units: A qualitative study. BMC Pediatrics, 14(230), 2-10.

Sahin, B., \& Karabekiroğlu, K. (2018). Bebek ruh sağlığında Erken müdahale programları. Turkiye Klinikleri J Child Psychiatry-Special Topics, 4(1), 69-76.

Sarparast, L., Farhadi, R., Sarparast, M., \& Shafai, S. (2015). The effect of Kangaroo Mother care on Neonatal outcomes in Iranian hospitals: A review. Journal Pediatrics Review, 3(1), 1-9. 
Stern, M., Karraker, K., Mclntosh, B., Moritzen, S., \& Olexa, M. (2006). Prematurity stereotyping and Mothers's interactions with their premature and full-term infants during the first year. Journal of Pediatric Psychology, 31(6), $597-607$.

Susan, M. (2013). Kangaroo care as a neonatal therapy. Newborn and Infant Nursing Reviews, 13(2), 73-75.

Tallandini, M. A., Morsan, V., Gronchi, G., \& Macagno, F. (2015). Systematic and meta-analytic review: triggering agents of parental perception of child's vulnerability in instances of preterm birth. Journal of Pediatric Psychology, 40(6), 545553.

Teti, D. M., Hess, C. R., \& O'Connell, M. (2005). Parental Perception of Infant vulnerability in a preterm sample: Prediction from maternal adaptation to parenthood during the Neonatal period. Developmental and Behavioral Pediatrics, 26(4), 283-292.

Thomasgard, M., \& Metz, W. P. (1995). The Vulnerable Child Syndrome revisited. Journal of Developmental \& Behavioral Pediatrics, 16(1), 47-53.

Thomason, E., Flynn, H. A., Himle, J. A., \& Volling, B. L. (2015). Are Women's parentıng-specifıc Beliefs Associated with depressive symptoms in the perinatal period? Development of the rigidity of maternal Beliefs scale. Depression and Anxiety, 32, 141-148.

Unal, D., \& Çak Esen, T. (2018). Anne Bebek İlişkisi ve sağlıklı bağlanma. Turkiye Klinikleri J Child Psychiatry-Special Topics, 4 (1), 1-4.

UNICEF. (2017). https://www.unicef.org.uk/babyfriendly/news-and-research/baby-friendly-research/researchsupporting-breastfeeding/skin-to-skin-contact/)

Venancio, S. I., \& Almeida, H. (2004). Kangaroo mother care: Scientific evidences and impact on breastfeeding. Jornal de Pediatria, 80(5), s173-s180.

WHO. (2012). Born too Soon The Global Action Report on Preterm Birth (ExecutiveSummary.ss:1-9 http://www.who.int/ pmnch/media/news/2012/201204_borntoosoon-execsum-eng.pdf)

WHO. (2015). WHO recommendations on interventions to improve preterm birth outcomes. Geneva. Switzerland.ss:1-98.

Yavaş Çelik, M., \& Çiğdem, Z. (2020). Kırılgan Bebek algısı Ölçeği: Geçerlilik ve güvenilirlik Çalışması. Psikiyatri Hemşireliği Dergisi, 11(3). doi:10.14744/phd.2020.92678 